\title{
Language Barrier is the cause of Stress among International Students of Universitas Airlangga
}

\author{
Shahzad Ali 1, Nono Hery Yoenanto ${ }^{2}$, Duta Nurdibyanandaru ${ }^{3}$ \\ 1,2,3 Developmental and Educational Psychology Department, Fakultas Psikologi \\ Universitas Airlangga, Surabaya, Indonesia \\ ${ }^{1}$ shahzad.ali-2018@psikologi.unair.ac.id, ${ }^{2}$ nono.hery@psikologi.unair.ac.id \\ 3 duta.nurdibyanandaru@psikologi.unair.ac.id
}

\begin{abstract}
Article Info
Article history:

Submitted Sept 14, 2020

Revised Sept 30, 2020

Accepted Oct 29, 2020

Published Nov 03, 2020
\end{abstract}

\section{Keywords:}

Language Barrier,

Stress,

Academic,

International Students

\begin{abstract}
Advanced education system and globalization are attractive towards the students to move a foreign country for achieving higher education. Indonesia is a multicultural and multi-linguistic country where every year hundreds of students coming to get higher education in Masters and $\mathrm{PhD}$ in various disciplines of education which are taught in Indonesian language. There are number of students joining Universitas Airlangga for the purpose of higher education on different programs. The current investigation defines the problem of language barrier is causing of stress in regard of academics among international students. There were 70 international students contributed in current study. The study finds $68 \%$ of participants suffering with the stress of language barrier in academics for international students. The findings of current study indicated the mainstream of international students experiencing in adopting the language barrier which is becoming the cause of stress for them. This study also suggested to the administrative stack-holders of Universitas Airlangga to pay attention this issue and need to overcome this major problem by organizing some events within the campus with local students. Such recommendations will help to cope this issue among international students by learning in a lenient and practical way.
\end{abstract}

\section{Corresponding Author:}

Nono Hery Yoenanto

Developmental and Educational Department, Fakultas Psikologi

Universitas Airlangga

Jl. Airlangga, Gubeng, Surabaya, Indonesia.

Email: nono.hery@psikologi.unair.ac.id

\section{INTRODUCTION}

Globalization is the coin in which nations across the world are emerging and all sectors of the life including education, (Sawir, 2005). Being foreign students in other countries generate various advantages,(Lillyman, S., \& Bennett, 2014). According to (Warring, 2010), being as foreign student create wonderful opportunities in interacting to local students and teachers of the institution that can help to grow the confidence level among international students. Moreover, because of studying abroad, students may get the opportunity to be employee universally and privileged personality in their country,(Campbell, 2010). Whereas students has some advantages, at the same host institution get numerous advantages on having number of foreign students,(Perry, 2012). Especially in the sector of finance which is very beneficial for host institution. Current study was conducted to elaborate the serious concerns related to the stress of language barrier among international students who currently enrolled in Universitas Airlangga.

Number of researches has been conducted on the topic of adjustment problems on students that take stay in foreign country for the purpose of education, in this new environment they have to face several issues regarding culture and customs of the host country. The mainstream of students go through in struggling by facing sufficient 
stressors, one of the major stress they face is language barrier, (Poyrazli, S., \& Grahame, 2007). The other stressors faced by international students are loneliness, (Sawir, E., Marginson, S., Deumert, A., Nyland, C., \& Ramia, 2008), homesickness (Ali, S., Yoenanto, N. H., \& Nurdibyanandaru, 2020), cultural shock (Constantine, M. G., Anderson, G. M., Berkel, L. A., Caldwell, L. D., \& Utsey, 2005); (Reynolds, A. L., \& Constantine, 2007), economic issues (Poyrazli, S., Arbona, C., Bullington, R., \& Pisecco, 2001), perceived discrimination (Karuppan, C. M., \& Barari, 2010), less social support (Pedersen, 1991).

The stressors are stated above shows that the major stressors has been faced by international students is language barrier, (Mori, 2000). A significant variable being as stressor in a host country's culture is language barrier, (Yeh, C. J., \& Inose, 2003). A number of studies proven the strong correlation between academic achievement and proficiency in language of host country. Several researches has resulted in that language barrier is major stress that is faced by international students in regards of their academic performance, (Lin, J.C.G., \& Yi, 1997);(Fatima, 2001). International students experienced problems in paying attention while communicating with locals because of not having enough information of host country social norms, poor vocabulary, and hard work for meeting their writing skills in academics as per the requirement,(Sawir, E., Marginson, S., Forbes-Mewett, H., Nyland, C., \& Ramia, 2012). A study conducted by (Brown, L., \& Holloway, 2008) on linguistic competency resulted in the participants of this study having stress because of language barrier in their academics. The researchers of the study investigated the international students by using the expressions of "ashamed", "embarrassed", "nervous", "not confident", and "scared" to investigate the international student's emotions in concern of language skill and ability. Students having less confidence about language skills might avert in participation and can also present their shunning behaviour, (Natowitz, 1995).

A study conducted by (Liu, M., s \& Redfern, B. (1997), investigated the problems experienced by international students while looking or searching the books in library in the United States. International students do not have enough confidence because of language barrier and their skills in speaking English to looking for help by staff in library and they ask help from their friends. Such experiences of international students elaborate the effect of language barrier by not visiting the library on regular basis. Another study by (Ishimura, Y., Howard, V., \& Moukdad, 2007), talked about this issue in his study on Japanese students that are studying in different universities in Canada. He mentioned in his study, Japanese students very rarely visits library in the universities because of not having enough confidence in their language skill. (Zhang, 2006)stated that, this problem happened because of basic difference for communicating among West and East (low context vs high context), so such variations effects the erudition skills in students.

There are couple of questions related to language stress have to discussed. First one is, what is language stress? And how it is significant to learn and speak host country language? Another question is, why new language generate the stress as compare to native language? Language stress will describe by two methods; first one is, this language stress trigger the sentiment of human which can bring several factors of arrangements regarding situation, (Purcell-Gates, V., McIntyre, E., \& Freppon, 1995). Supposed that, a student who have shy personality can face stress on asking for talking on a topic in front of class, (Horwitz, E. K., Horwitz, M. B., 1986). The second one is, because of uniqueness in experiencing of new language learning is the cause of making an individual stress or nervous. Such feelings of stress and nervousness limited situation in learning of new language, this become the cause of peculiar or particular stress. According to its specification, psychology differentiate it as specific stress by mentioning individuals of having situational stress face this stress,(Horwitz, E. K., Horwitz, M. B., 1986). Generally, language stress is an extra experiment for the learner of new language and teachers as well. 
Moreover, another challenge for international students is facing remoteness with class-fellows and interaction with lecturers because of language barrier. A study by (Terui, 2012), indicated that, number of foreign scholars who are studying in the United States of America struggling in communicating with local people by ways of "ethnography" because of low proficiency in English. Another study by (Beoku-Betts, 2004) has found that, international female students who were enrolled in science faculties in different universities in region of Western experiencing that lecturers of those universities are less supportive and questioning to those female students by criticizing their English accent.

Problem regarding language problem among international students are mostly have seen in Australia, the United States of America and the United Kingdom, students experienced problems in verbal, oral and writing in these countries,(Robertson, M., Line, M., Jones, S. and Thomas, 2000);(Singh, 2005). As per the investigation of (Hellstén, M., \& Prescott, 2004), concluded that problems regarding language is also enforce time pressure, for example; recording the lectures, listening these recordings again and again, pressure of academic achievement by completing the study tasks on the time. A number of students have difficulties in pronouncing the host country language, (Singh, 2005). According to the study of (Stoynoff, 1997), proficiency in language is significantly interlinked with academic performance of foreign students.

A study by (Campbel, N., \& Zeng, 2006) on Chinese students in Australia and New Zealand has find that, Chinese students do not have much domestic friends in host countries and they feel developing friendship with domestic students is hard than making friends with other international student group who are studying in same institution, as per the findings they also mention the causes of this problem among Chinese students is linguistic barrier, not mutual concerns and lifestyles. That's why they preferred to live in Chinese community than making friendship in host community, this is all because Chinese students facing language barrier and are not able to speak English fluently. Though, several studies has proven that local students feels hesitant and less confident in communicating to foreign students because of having linguistic barrier, different culture and different origin, (Harrison, N., \& Peacock, 2010); (Kimmel, K., \& Volet, 2012). Another study by (Barger, 2004) has concluded that healthy communication among both domestic and foreign students may transfer mutual friendly relationship and can have good effect in transferring linguistic, culture and academic experiences.

The purpose of the current study was to elaborate the language barrier problem is a cause of stress in foreign students who are studying in a quite well established and well organized Universitas Airlangga.

\section{THEORY AND METHODS}

There are number of researches that has resulted in, foreign students face multiple challenges in a hosting country such as adjustment problem, unfamiliar about culture and people, not socialization, and language barrier,(Gautam, C., Lowery, C. L., Mays, C., \& Durant, 2016). A study by (Wright, C., \& Schartner, 2013), which is conducted among foreign students who are enrolled in multiple universities and colleges in the United Kingdom, exposed that foreign students experiencing frustration and stress while interacting with natives, faculty members and adaptation of culture. (Park, S.S., \& Son, 2011), conducted a study with focus of difficulties of language and adopting the culture. Other than language and culture adaptation problems, international has to face economic and socialisation problems which also a great challenge to them, it bring the stress and feeling of loneliness among foreign students. 
International students face number of experiments in their academics while studying in host country. One of them is language barrier which play key role in communication and achieving good academic grades, (Galloway, F. J., \& Jenkins, 2009). Current study main focus is language barrier effects on academic attaining among international students which also leads toward stress in learning. A study by (Robertson, M., Line, M., Jones, S., \& Thomas, 2000), institution staff relationship with international students has indicated that, staff of institution does not show concern of language barrier problem facing by international students by stating, international students should have to bring advancement in learning new language. Numerous researches has resulted in favour international students experiencing language barrier. In a study by (Liu, 2011), she shared her personal experience of surviving while studying in Canada.

Attaining higher education in abroad is full of challenges, previous studies has proved that foreign scholars face number of challenges while adjusting new environment which they never experienced before and it may affect academics of them because of language barrier. At the other hand, institutions play role in serving to foreign students by supporting them and arranging some events for them to overcome such issues but there are still problems has experiencing by international students in adjustment and learning language in new culture,(Wu, H. P., Garza, E., \& Guzman, 2015). It is all because of cultural shock and foreign students cannot run away or neglect the reality of this cultural shock, these all are the part of acculturating process while adjusting in new country. This process resulted in changing in biological, physiological, establishing new contact/relationships in host society, and behavioral or psychological changes in international students, ,(Berry, J. W., Kim, U., Minde, T., \& Mok, 1987).

Hence, hosting institutions should make a setting in which foreign students can make their interaction with a supportive environment in regard of attaining their goal for what they have migrate to the host institution and country, (Sherry, M., Thomas, P., \& Chui, 2010). They also identified adjusting problems regarding culture, less interaction with domestic mates and language in international students.

The belief of having foreign education acquaintance being as international students is enhancing gradually from last couple of decades, (Ali, S., Yoenanto, N. H., \& Nurdibyanandaru, 2020). As far as the expectedness of foreign educational acquaintance lies at one side, at the other side the language is important factor to achieve this dream. Same as like, Indonesian education system have its own educational system which is taught in Bahasa Indonesia. In last one decade the number of international students is enhancing year by year in Indonesian universities through various educational programs such as Kemitraan Negara Berkembang (KNB) scholarships and Dharmasiswa language learning program.

Either such programs are beneficial for the foreign students in context of learning basic level of Bahasa Indonesia but at the same time it is a cause of stress among international students in Indonesia. The reason is, Bahasa Indonesia is not an international language and the students who are joining Indonesian education system each year have their previous education in English or their local language. So, this is language barrier is a cause of stress for a limit.

As national language of Indonesia, Bahasa Indonesia is widely spoken across the Indonesia. At the other side, it is a language barriers for international students and precise it as stress or face nervousness while communicating the local people. Sometimes the feel "mental block" while practicing Bahasa Indonesia that cause of stress too. It is apparent naturally from the learners of new language and discovered as greatly observed variable in education and psychology,(Hashemi, 2011). Stress bring into being hinder by several ways of learning, however association with erudition called as "foreign or second language" and coined as language stress. Language barrier is also a cause of experiencing difficulties among foreign students Universities,(Robertson, M., Line, M., Jones, S. and 
Thomas, 2000). One of the difficulties that language barrier generate is lack of socialization, that could be head towards several unhelpful results. Several research investigators correlate it with feeling of stress, anxiety and facing asocial challenges in host country, (Trice, 2004). Such difficulties might lead towards adjustment in academics that is new for a student.

Students from trans-border enrolled in the Universitas Airlangga to pursue advanced education in the Republic of Indonesia, should have to learn the Bahasa Indonesia. Hence, having amount of international student's enrolment in Universitas Airlangga, Bahasa Indonesia is new language for them, and number of international students stated their major problem while learning and staying in Indonesian society is language barrier.

Foreign students in same university belong to different countries may create their own group on nation basis because of afraid of being isolated in new environment. Institution can play a vital role in avoidance of such sub-cultural groups based on nations and may bring harmony among international students for bot experiencing isolation and stress in foreign students,(Rienties, B., Beausaert, S., Grohnert, T., Niemantsverdriet, S., \& Kommers, 2012). Education institution considered as main location for all foreign students, where international students learn not for only adaptation in academics but cultural, social and linguistic adaptation also in regard of avoiding the space of isolation among international students,(Biserova, G. K., \& Shagivaleeva, 2019).

\subsection{Psychological effects on socio-cultural adjustment}

There are two phases of adjustment that international students faces while adopting new environment (i) psychological adjustment and (ii) socio-cultural adjustment, both are take process to some extent in adjustment, (Berry, 2006). Evolving with process about coping stress, satisfaction and wellbeing are related with psychological adjustment, (Lazarus, R. S., \& Folkman, 1984). Individual difference is matter also in this adjustment because it also relate with personality (Zhang, J., \& Goodson, 2011), which means to identify the difference between host culture and home culture,(Playford, K., \& Safdar, 2007). In previous studies it has shown that international students suffering with language barrier with this psychological and socio-cultural adjustment which resulted in stress and effect their academic performance,(Aune, R. K., Hendreickson, B., \& Rosen, 2011). There is other factor that international students face is discrimination, as per the study of, (Smith, R. \& Khawaja, 2011) international students in Canadian institution experience serious stress about discrimination on having language barrier.

Communication between people from different cultural background may swing into progress of language learning and overcoming language barrier that can also help in developing social exchange, contacts, communication and relationship between individuals having different cultural background by sharing. Communication among foreign and local students can help too in developing joint working environment that would help in overcoming stress of being discriminated in host country,(Berry, 2006); (Li, A. \& Gasser, 2005). A study by (Hickey, T., O’Reilly, A. \& Ryan, 2010) investigated that support from the host country community is helping to international students to reduce their feelings of stress and being alone, and helping them to adjusting culture of host country.

From last one decade, each year scholars are moving to other countries like The United States of America, European countries, Canada, Australia and Asia for attaining higher education in multiple fields of education. This experience by scholars or students are not only earnest good education but having an international cultural experience by staying these regions and they experience various new culture which they never experienced before such as learning new languages of different ethnic groups on host countries, (Chen, H., \& Zimitat, 2006); (Qun, W., Syhabuddin, Mulyati, Y., Damaianti, 2018). 
While living in new culture and education system, international students not only achieve their academics but go through with the survival of acculturation of the living country; learning customs, values, norms and language of the community where they are living, (Huang, 2014).

Though, while living in host culture foreign students go through with stress while learning, such as academic learning methods and barrier of language because of acculturation of the society,(Qun, W., Syhabuddin, Mulyati, Y., Damaianti, 2018). Either they already have in their mind or ready to experience new changes in abroad, still these changes might resulted in cultural shock for students,(Xiaoqiong, 2008). Recent researches grounded on foreign students indicated that international students are facing cultural shock in regard of living in host country and make come recommendations for the hosting institution in adjustment in new culture, (Snoubar, Y., \& Celik, 2013); (Shieh, 2014).

Adopting a new cultural works as addition in socialization but to some extent establishing the communication between two different culture, nations, and communities, (Bierwiaczonek, K., \& Waldzus, 2016). One of the serious concern about international students is assertion in any foreign educational institution. Low assertion can be cause of "interpersonal conflict", such as stress, anxiety and difficulties in academics that may affect profession in future and rise of unfriendliness attitude in individual, (Chirkov, V., Vansteenkiste, M., Tao, R., \& Lynch, 2007). The mutual problems that number of foreign scholars are experience is language barrier, new academic system, psychological and cultural adaptation, (Biserova, G. K., \& Shagivaleeva, 2019);(Ecochard, S., \& Fotheringham, 2017);(Zakirova, A. F., \& Volodina, 2018).

\subsection{Definition of Stress}

It is a state of mind where an individual have faced unpredictable challenges and struggle to deal with such challenges that might linked with personal, job, financial crisis, environmental factors, cultural adaptation and so on, (Fink, 2016).

\subsection{Types of stress}

Acute Stress

It is a type of stress that might face by an individual for a short-time and have a peculiar purpose related to any subject. For example, having a task for a limited time duration and compression for a specific condition. Like students have a time frame to complete their assignments in a due time, (Bryant, 2017).

\section{Episodic Acute Stress}

This type of stress have been face acute stress often by an individual. An individual who live currently in a constant causes of stress. People who often face "acute stress" might have unstable life. Such individuals all the time in a crisis of psychological pressure, (LeBlanc, 2009).

\section{Chronic Stress}

Chronic stress involved in demands that are currently ongoing, this type of stress can be psychological damage for an individual mental condition. Sometimes, individuals going through with this but they do not bring into their conscious state of mind, (Marin, T. J., Martin, T. M., Blackwell, E., Stetler, C., \& Miller, 2007).

\section{Method}


For achieving the aim of this study, the researcher used self-developed questionnaire in regard of finding the language issues between international students belong to different cultural background, studying in Universitas Airlannga. Alongside this, current investigation using previous studies literature review as analysis, primary and secondary observation.

The researchers "personal data sheet" which covers (nationality, residing time duration in Indonesia, language class course). The self-developed questionnaire based on two sections; language barrier and adjustment in academics for obtaining their higher education in Universitas Airlangga.

The key concentration from the researchers were foreign students are currently studying and residing from last two years in Univeristas Airlangga. There were 70 participants who participated in this study. The foreign students belongs to 3 continents, Asia, Africa and Europe.

\section{RESULT AND DISCUSSION}

Table1 shows the significant result by using the chi square test.

Figure.1

\begin{tabular}{|c|c|c|c|}
\hline & \multicolumn{2}{|r|}{ Chi-Square Tests } & \\
\hline & Value & $\mathrm{df}$ & Asymptotic Significance (2-sided) \\
\hline Pearson Chi-Square & $23.239^{\mathrm{a}}$ & 6 & $\begin{array}{rr}.001 \\
\end{array}$ \\
\hline Likelihood Ratio & 27.410 & 6 & .000 \\
\hline $\begin{array}{l}\text { Linear-by-Linear } \\
\text { Association }\end{array}$ & 7.263 & 1 & .007 \\
\hline $\mathrm{N}$ of Valid Cases & 70 & & \\
\hline
\end{tabular}

a. 8 cells $(57.1 \%)$ have expected count less than 5 . The minimum expected count is 1.29 .

The result in Table1 indicating the language barrier is linked with stress among international students with Pearson Chi-Square significance .0001 and Linear-by-linear Association significance results .007 in Table1. Further, as per the study of (Jones, 2004), he stated that having cultural reasons and new language which they never heard before is very hard to understand that may cause of generating the stress among international students because of this language barrier, his study supporting the current study results that shows in Table1. Learning the guest country language and problem in speaking, understand and communicating appeared by way of foundation of stress for international students.

\section{Figure.2}

I found Bahasa Indonesia very hard to

\begin{tabular}{l|c|r|r} 
understand? & Mean & $\mathrm{N}$ & \multicolumn{2}{c}{ Std. Deviation } \\
\hline Yes & 1.3171 & 41 & .47112 \\
\hline No & 1.5862 & 29 & .50123 \\
\hline Total & 1.4286 & 70 & .49844 \\
\hline
\end{tabular}


There were 70 participants who responded of this item, the number of students who says "yes" is 41 by the mean 1.31 with standard deviation .47 . That indicates majority of the students are experiencing this language barrier problem and cause if stress among international students. A study was conducted in Kazan University Russia by (Ibragimova, E. R., \& Tarasova, 2018), they found the similar results in their study. In that study the same question was asked by international students who were studying in Kazan University, majority of the participants shows their concern of facing stress because of language barrier. As per the supporting results of previous study are forwarding the current study results which is quite majority of international students are concerning the same issue.

\section{Figure.3}

Language sometimes make me low mood in the class?

\begin{tabular}{lc|c|cr}
$\begin{array}{l}\text { Language sometimes make } \\
\text { me low mood in the class? }\end{array}$ & Mean & N & \multicolumn{2}{|c}{ Std. Deviation } \\
\hline Yes & 1.3958 & 48 & .49420 \\
\hline No & 1.5000 & 22 & .51177 \\
\hline Total & 1.4286 & 70 & .49844 \\
\hline
\end{tabular}

Table 3 results are highly concerned with response of 48 out of 70 respondents of stress because of language barrier by indicating the mean 1.39 and standard deviation with .49. Forty eight students shows their stress and how it is affecting their academics.

The results in Table 3 indicating that the respondents are experiencing the strict language barrier environment of the classroom is becoming the cause of lowering their interest in academics. However, such observations should be consider as an indicator institution and university professors should pay attention to the concerns that are causing of less interest in academics among international students. The current results are has been supporting by the study of (Ohata, 2005), in his study, he found that strict classroom environment regarding language and teachers are not focusing the anxiety among international students because of not fixing with themselves in English.

Figure. 4

I missed some important information because of language barrier?

\begin{tabular}{|c|c|c|c|}
\hline $\begin{array}{l}\text { I missed some important } \\
\text { information because of } \\
\text { language barrier? }\end{array}$ & Mean & $\mathrm{N}$ & Std. Deviation \\
\hline Yes & 1.3966 & 58 & .49345 \\
\hline No & 1.5833 & 12 & .51493 \\
\hline Total & 1.4286 & 70 & .49844 \\
\hline
\end{tabular}


Table 4 is indicating that the international students facing stress because of language barrier. Mainstream of the respondents are 58 whose express their problem by selecting "Yes" are missing important information in their academics with the mean 1.39 and standard deviation .49, which is clearly showed language barrier stress for academics. A study was conducted in the Aberystwyth University United Kingdom by(Foley, 2010), concluded that $60.3 \%$ participants of the study indicated that the language barrier is very hard for them to manage their academics because of language barrier of English in Aberystwyth University, which is supporting the current study findings and the researcher come to the point after the analysis of study by(Foley, 2010), students in Universitas Airlangga facing this language barrier stress too and missing some important information which is indirectly affecting their academics.

\section{ANALYSIS}

The investigators found that language barrier is serious and concerned problem among international students of the Universitas Airlangga, and they are experiencing this barrier in their academics. In the table 1 the overall results of current study highly concluded by showing the significant results of Chi-Square test .01 and Linear-by-linear Association significance results .007 of 70 international students respondents who are currently studying in the Universitas Airlangga. From the table 2 results, students are facing problem while understanding and communicating with peer groups, teachers and staff because of the language barrier and it is cause of arisen the stress among international students of the Universitas Airlangga. The reason is that before enrolling in Universitas Airlangga they were not able to speak and understand a single word of Bahasa Indonesia. The majority of teachers and students in the same class are unable to speak English and academic classes in Bahasa Indonesia too in the campus.

Table 3 and table 4 are about to the academics problems that also showing the international students experiencing poor skills in class participation and in academics which become the cause of lowering their interest in studies and they missed some important notes regarding their subjects because of the language barrier and it generating stress among international students of Universitas Airlangga. In the class while delivering the lectures by teachers the language they used is Bahasa Indonesia which is unable to understand and make them low mood in the class participation. Language barrier is also a cause of not showing their interests in class participation and other work. International students missed some important information and they do not take serious their assignments in a proper way in the comparison of local Indonesian classmates who participate the class participation openly. At the other hand this might generate sense of aloofness among international students of the Universitas Airlangga.

Because of less scope of Bahasa Indonesia language for other countries, the newly learners of Indonesian language experienced language stress while learning, that is not a positive sign for them especially competency of communication, (Kusumaningrum, 2016). As per the study of (Gregersen, T., \& Horwitz, 2002), stated that international students are not feeling comfortable while communicating in Bahasa Indonesia because they are facing pressure of making mistakes while speaking that trigger the stress among international students.

Studies by (Grebennikova, 2011); (Bekker, I. L., \& Ivanchin, 2015) resulted in there are multiple internal and external factors involved in adapting new culture for international students, some psychological (internal factors) such as language and communication skills should have key importance from the host institution in learning 
these skills by providing friendly teaching environment which can motivate them in taking personal attention towards learning language that would help international students in their academics and establishing social relationship in the host community for learning the local culture.

\section{CONCLUSION}

For overcoming such issues, the authorities of the Universitas Airlangga should have to take some serious steps toward solution. First, they should increase the time duration of language learning classes from 6 months to 1 year for international students. Secondly, administration should have to ask their professors and staff to learn English language because of importance in the world. Thirdly, teachers should have to cooperate with international students in their work that can make them able to feel relax in concern of their academics.

Language Centre of the Universitas Airlangga should have to organize number of events half of year regularly that can create the platform where international students may interact with old learners of Bahasa Indonesia that can share their experiences and techniques for learning to overcome language barrier stress in newly enrolled international students. Administration of the university should organized some competition environment among new learners by using the way of reinforcement and distribute the rewards for winners. This can be cause of generating motivation in learning Bahasa Indonesia and with this way they can interact with authorities of the Universitas Airlangga which can be a positive gesture for international students.

In this period of globalization, it becomes very essential for host institution and professors of the institution should have to adjust or adopt an environment where foreign students may able to feel easy in interacting with faculty members and other staff of institution that can also help to international students to overcome their problem that they are experiencing by living in host institution and culture, this would help also in attaining good academic score in international students. The major problem that experience by foreign students is language barrier in host country academic culture. Such modification should bring as per the views of foreign students.

Authors suggests too to the authorities of the Universitas Airlangga, they should have establish a research focus which can be specific to conduct the surveys or interviews in concern of international students to know their current situation.

For lessening these issues among international students need to engage healthy and skilful communication in both foreign and local students, and for achieving this purpose, host institution can play a vital role in developing positive relationships.

Additionally, there is further space to investigate the problems of international students in the Universitas Airlangga. Authors highly recommended to the researchers to conduct such researches to identify the other problems among international students.

\section{ACKNOWLEDGEMENT}

All authors of this study highly appreciate all participants who participated in the study without having any objection. Special thanks to the Fakultas Psikologi Universitas Airlangga to allowing the authors for conducting this research.

\section{REFERENCES}

Ali, S., Yoenanto, N. H., \& Nurdibyanandaru, D. (2020). Acculturative Stress among international students at Airlangga University-. Society, 8(1), 123-135. 
Aune, R. K., Hendreickson, B., \& Rosen, D. R. (2011). An analysis of friendship networks, social connectedness, homesickness, and satisfaction levels of international students. International Journal of Intercultural Relations, 35, 281-295.

Barger, S. S. (2004). The impact of international students on domestic students in United States institutions of higher education (Doctoral dissertation, The University of Wisconsin-Madison).

Bekker, I. L., \& Ivanchin, S. A. (2015). Problems of adaptation of international students to the educational process of the Russian university (on the example of Penza State University). Izvestiya Vysshikh Uchebnykh Zavedenii. The Volga Region. Humanitarian Sciences, 4(36), 247-257.

Beoku-Betts, J. (2004). African women pursuing graduate studies in the sciences: Racism, gender bias, and third world marginality. NWSA Journal, 116-135.

Berry, J. W., Kim, U., Minde, T., \& Mok, D. (1987). Comparative studies of acculturative stress. International Migration Review, 21(3), 491-511.

Berry, J. W. (2006). Immigrant youth: Acculturation, identity and adaptation. Applied Psychology, 55(03), 303-332.

Bierwiaczonek, K., \& Waldzus, S. (2016). Socio-cultural factors as antecedents of crosscultural adaptation in expatriates, international students, and migrants: A review. Journal of Cross-Cultural Psychology, 47((6)), 767-817.

Biserova, G. K., \& Shagivaleeva, G. R. (2019). Socio-psychological adaptation of international students to learning and professional activities. Space and Culture, India, 6(5), 99-114.

Brown, L., \& Holloway, I. (2008). The initial stage of the international sojourn: excitement or culture shock? British Journal of Guidance \& Counselling, 36(1), 33-49.

Bryant, R. A. (2017). Acute stress disorder. Current opinion in psychology. Current Opinion in Psychology, 14, 127-131.

Campbel, N., \& Zeng, J. (2006). Living in the West: A study of Chinese international students' adaptation. Communication Journal of New Zealand, 7(1).

Campbell, A. (2010). Developing generic skills and attributes of international students: The (ir) relevance of the Australian university experience. Journal of Higher Education Policy and Management, 32(5), 487-497.

Chen, H., \& Zimitat, C. (2006). Understanding Taiwanese students' decision-making factors regarding Australian international higher education. International Journal of Educational Management, 20(2), 92-100.

Chirkov, V., Vansteenkiste, M., Tao, R., \& Lynch, M. (2007). The role of self-determined motivation and goals for study abroad in the adaptation of international students. International Journal of Intercultural Relations, 31(2), 199-222.

Constantine, M. G., Anderson, G. M., Berkel, L. A., Caldwell, L. D., \& Utsey, S. O. (2005). Examining the cultural adjustment experiences of African international college students: A qualitative analysis. Journal of Counseling Psychology, 52(1), 57.

Ecochard, S., \& Fotheringham, J. (2017). International students' unique challenges-Why understanding international transitions to higher education matters. Journal of Perspectives in Applied Academic Practice, 5(2), 100-108.

Fatima, N. (2001). International female graduate students' perceptions of their adjustment 
experiences and coping strategies at an Urban Research University.

Fink, G. (2016). Stress: concepts, definition and history. Change.

Foley, 0. (2010). An investigation into the barriers faced by international students in their use of a small Irish academic library (Doctoral dissertation, Aberystwyth University).

Galloway, F. J., \& Jenkins, J. R. (2009). The adjustment problems faced by international students in the United States: A comparison of international students and administrative perceptions at two private, religiously affiliated universities. NASPA Journal, 46(4), 661-673.

Gautam, C., Lowery, C. L., Mays, C., \& Durant, D. (2016). Challenges for global learners: A qualitative study of the concerns and difficulties of international students. Journal of International Students, 6(2), 501-526.

Grebennikova, I. A. (2011). The process of adaptation of international students: the mechanism and key factors. Humanitarian Research in Eastern Siberia and the Far East, 3, 98-100.

Gregersen, T., \& Horwitz, E. K. (2002). Language learning and perfectionism: Anxious and non-anxious language learners' reactions to their own oral performance. The Modern Language Journal, 86(4), 562-570.

Harrison, N., \& Peacock, N. (2010). Cultural distance, mindfulness and passive xenophobia: Using Integrated Threat Theory to explore home higher education students' perspectives on 'internationalisation at home'. British Educational Research Journal, 36(6), 877-902.

Hashemi, M. (2011). Language stress and anxiety among the English language learners. Procedia-Social and Behavioral Sciences, 30.

Hellstén, M., \& Prescott, A. (2004). Learning at University: The international student experience. International Education Journal, 5(3), 344-351.

Hickey, T., O’Reilly, A. \& Ryan, D. (2010). The Psychological Well-being and Sociocultural Adaptation of Short-Term International Students in Ireland. Journal of College Student Development, 51(5), 584-598.

Horwitz, E. K., Horwitz, M. B., \& C. (1986). Foreign language classroom anxiety. The Modern Language Journal, 70(2), 125-132.

Huang, Y. (2014). Constructing intercultural communicative competence framework for English learners. Cross-Cultural Communication, 10(1), 97-101.

Ibragimova, E. R., \& Tarasova, A. N. (2018). Language-related problems of international students of Elabuga Institute of Kazan Federal University. Revista ESPACIOS, 39(2).

Ishimura, Y., Howard, V., \& Moukdad, H. (2007). Information literacy in academic libraries: Assessment of Japanese students' needs for successful assignment completion in two Halifax universities. Canadian Journal of Information and Library Science, 31(1), 1-26.

Jones, J. F. (2004). A cultural context for language anxiety. English Australia Journal, 21(2), 30.

Karuppan, C. M., \& Barari, M. (2010). Perceived discrimination and international students' learning: an empirical investigation. Journal of Higher Education Policy and Management, 33(1), 67-83.

Kimmel, K., \& Volet, S. (2012). University students' perceptions of and attitudes towards culturally diverse group work: Does context matter?. Journal of Studies in 
International Education, 16(2), 157-181.

Kusumaningrum, Y. I. (2016). The effect of aptitude toward the adaptability in social interaction. In Ninth International Conference on Applied Linguistics (CONAPLIN 9). Atlantis Press.

Lazarus, R. S., \& Folkman, S. (1984). Stress, appraisal, and coping. Springer Publishing Company., 150-153.

LeBlanc, V. R. (2009). The effects of acute stress on performance: implications for health professions education. Academic Medicine, 84(10), 525-533.

Li, A. \& Gasser, M. (2005). Predicting Asian international students' sociocultural adjustment: A test of two mediation models. International Journal of Intercultural Relations, 29(5), 561-576.

Lillyman, S., \& Bennett, C. (2014). Providing a positive learning experience for international students studying at UK universities: A literature review. Journal of Research in International Education, 13(1), 63-75.

Lin, J.C.G., \& Yi, J. K. (1997). Asian international students' adjustment: Issues and program suggestions. College Student Journal, 31(4), 473-480.

Liu, L. (2011). An international graduate student's ESL learning experience beyond the classroom. TESL Canada Journal, 77-92.

Marin, T. J., Martin, T. M., Blackwell, E., Stetler, C., \& Miller, G. E. (2007). Differentiating the impact of episodic and chronic stressors on hypothalamic-pituitary-adrenocortical axis regulation in young women. Health Psychology, 26(4), 447.

Mori, S. (2000). Addressing the mental health concerns of international students. Journal of Counseling and Development, 78(2), 137-144.

Natowitz, A. (1995). International Students in US Academic Libraries: Recent Concerns and Trends. Research Strategies, 13(1), 4-16.

Ohata, K. (2005). Language anxiety from the teacher's perspective: Interviews with seven experienced ESL/EFL teachers. Journal of Language and Learning, 3(1), 133-155.

Park, S.S., \& Son, J. B. (2011). Language difficulties and cultural challenges of international students in an Australian university preparation program. In A. Dashwood (Ed.),. Language, Culture and Social Connectedness, 35-55.

Pedersen, P. B. (1991). Counseling international students. The Counseling Psychologist.

Perry, C. J. (2012). Comparing international and American students' challenges: A literature review. Journal of International Students 2016, 6(3), 712-721.

Playford, K., \& Safdar, S. (2007). Various conceptualization of acculturation and the prediction of international students adaptations. In A. Chybicka, \& M. Kazmierczak (Eds.),. Appreciating Diversity: Cultural and Gender Issues, 37-66.

Poyrazli, S., \& Grahame, K. M. (2007). Barriers to adjustment: Needs of international students within a semi-urban campus community. Journal of Instructional Psychology, 34(1), 28.

Poyrazli, S., Arbona, C., Bullington, R., \& Pisecco, S. (2001). Adjustment issues of Turkish college students studying in the United States. College Student Journal, 35(1), 52-52.

Purcell-Gates, V., McIntyre, E., \& Freppon, P. A. (1995). Learning written storybook language in school: A comparison of low-SES children in skills-based and whole 
language classrooms. American Educational Research Journal, 32(3), 659-685.

Qun, W., Syhabuddin, Mulyati, Y., Damaianti, V. S. (2018). ). Perceiving and Dealing with Culture Shock: The Study of Chinese Indonesian-language Students. Indonesian Journal of Education, 11(1), 18-28.

Reynolds, A. L., \& Constantine, M. G. (2007). Cultural adjustment difficulties and career development of international college students. Journal of Career Assessment, 15(3), 338-350.

Rienties, B., Beausaert, S., Grohnert, T., Niemantsverdriet, S., \& Kommers, P. (2012). Understanding academic performance of international students: The role of ethnicity, academic and social integration. Higher Education, 63(6), 685-700.

Robertson, M., Line, M., Jones, S., \& Thomas, S. (2000). International students, learning environments and perceptions: A case study using the Delphi technique. Higher Education Research \& Development, 19(1), 89-102.

Robertson, M., Line, M., Jones, S. and Thomas, S. (2000). International students, learning environments and perceptions: A case study using the Delphi technique. Higher Education Research and Development, 19(1), 89-102.

Sawir, E., Marginson, S., Deumert, A., Nyland, C., \& Ramia, G. (2008). Loneliness and international students: An Australian study. Journal of Studies in International Education, 12(2), 148-180.

Sawir, E., Marginson, S., Forbes-Mewett, H., Nyland, C., \& Ramia, G. (2012). International student security and English language proficiency. Journal of Studies in International Education, 16(5), 434-454.

Sawir, E. (2005). Language difficulties of international students in Australia: The effects of prior learning experience. International Education Journal, 6(5), 567-580.

Sherry, M., Thomas, P., \& Chui, W. H. (2010). International students: A vulnerable student population. Higher Education, 60(1), 33-46.

Shieh, C. J. (2014). Effects of culture shock and cross-cultural adaptation on learning satisfaction of mainland china students studying in Taiwan. Revista Internacional de Sociología, 72(2), 57-67.

Singh, M. (2005). Enabling transnational learning communities: Policies, pedagogies and politics of educational power. Internationalizing Higher Education.Springer, Dordrecht, 9-36.

Smith, R. \& Khawaja, N. (2011). A review of the acculturation experiences of international students. International Journal of Intercultural Relations, 35(6), 699-713.

Snoubar, Y., \& Celik, G. (2013). Cultural Differences of International Students in Turkey and problems they experience. Science Direct, 106, 759-766.

Stoynoff, S. (1997). Factors associated with international students' academic achievement. Journal of Instructional Psychology, 24(1), 56.

Terui, S. (2012). Second language learners' coping strategy in conversations with native speakers. Journal of International Students, 2(2), 168-183.

Trice, A. G. (2004). Mixing it up: International graduate students' social interactions with American students. Journal of College Student Development, 45(6), 671-687.

Warring, S. (2010). Facilitating independence amongst Chinese international students completing a Bachelor of Applied Business Studies Degree. Innovations in Education 
and Teaching International, 47(4), 379-392.

Wright, C., \& Schartner, A. (2013). 'I can't... I won't?'International students at the threshold of social interaction. Journal of Research in International Education, 12(2), 113-128.

Wu, H. P., Garza, E., \& Guzman, N. (2015). International student's challenge and adjustment to college. Education Research International, 1-9.

Xiaoqiong, H. (2008). The culture shock that Asian students experience in immersion education. Changing English, 15(1), 101-105.

Yeh, C. J., \& Inose, M. (2003). International students' reported English fluency, social support satisfaction, and social connectedness as predictors of acculturative stress. Counselling Psychology Quarterly, 16(1), 15-28.

Zakirova, A. F., \& Volodina, Y. N. (2018). Trends and Prospects in Educational Modernisation: A Hermeneutic Approach. The Education and Science Journal, 20(9), 9-34.

Zhang, J., \& Goodson, P. (2011). Predictors of international students' psychosocial adjustment to life in the United States: A systematic review. International Journal of Intercultural Relations, 35(2), 139-162.

Zhang, L. (2006). Communication in academic libraries: an East Asian perspective. Reference Services Review. 